\title{
Benefit Adequacy in Funded Pension Systems: Micro-Simulation of the Israeli Pension Scheme
}

Submitted 11/03/21, $1^{\text {st }}$ revision 19/03/21, $2^{\text {nd }}$ revision 09/04/21, accepted 20/05/21

\author{
Ishay Wolf ${ }^{1}$, Lorena Caridad Lopez del Rio ${ }^{2}$
}

\begin{abstract}
:
Purpose: This paper aims to empirically examine the adequacy of the future benefits of the funded pension scheme.

Design/methodology/approach: This study investigates a large real data sample from the largest pension fund in Israel and simulates expected benefits using a pension simulator.

Findings: We found that even with relatively high market returns, the shift of pension provision from defined benefit $(D B)$ to DC entails a significant shift of risk from capital to labor and might lead elderly participants to poverty during their retirement phase. We find Israel's pension system to be a unique playground for exploring an almost pure defined contribution $(D C)$ pension system with a continuous trend toward capitalization and liberalization.

Practical implications: This paper details the need to implement risk-sharing mechanisms in funded schemes, which provide a risk cushion against market fluctuations and alleviate income inequality and poverty.

Originality value: Due to the pandemic crisis in 2020, we also showed that the expected pension benefits were vulnerable to financial, career, and systemic shocks.
\end{abstract}

Keywords: Funded pension scheme, social security, poverty, minimum pension guarantee, public policy, Israel.

JEL codes: H30, H53, J14, J38, G28.

Paper type: Research article.

${ }^{1}$ Ono Academic Center, Israel and Cordoba University, Spain, Ishay.wolf1@gmail.com

${ }^{2}$ Cordoba University, Spain. 


\section{Introduction}

The aging of societies is a challenge to public pensions, particularly Pay-As-You-Go (PAYG) systems, in which the working population finances the pensions of the retired. To secure financial sustainability, international organizations and national policy experts recommended a shift to a multi-pillar pension architecture with more funded elements (Holzmann and Hinz, 2005; Ortiz et al., 2020).

In recent years, not least since the financial market crash, pensions' social adequacy has become an important topic because of the response to financial sustainability problems (Orenstein 2011). Concerns about the consequences of funded pensions, such as the growing risks of poverty and the increase in inequality during old age, have mounted in academic and public debates (Grech, 2018).

The financial crisis of 2008 and the recent coronavirus financial crisis have demonstrated the sensitivity of old age expected benefits not only to the capital market (Lever and Michielsen, 2016) but also to continue working and savings. As a result, people's trust in the expected long-term returns of funded pensions has been shattered at a time when saving for retirement has become more critical. The privatization of the responsibility for old-age income and the shift toward more funded pensions raises important issues that warrant examination (Ebbinghaus, 2015).

Varying approaches to pension regulation induce various redistributive and wellbeing effects (Wolf and Lopez del Rio, 2021a; Barr, 2000). Notably, the effect of private pension income on income inequalities among the elderly is less clear, as the mass of workers that may benefit under the new reforms are expected to retire only in the next 5-10 years across the many Western countries that have implemented funded pension schemes (Bonenkamp et al., 2016; Thalassinos et al., 2019).

Contributing to this strand of pension scheme investigation, we aim to understand the long-term economic consequences of funded pension's benefits in the future and recognize the wide variety of financial, labor, and systemic risks. The question that arises subsequently is how to manage these risks efficiently on the central planner level. We empirically investigate the adequacy of pension benefits and the probability of people falling into poverty during their old age. Following the COVID-19 pandemic in 2020, the realization of financial risks associated with frictions in the labor markets and global systemic risk provided the opportunity to investigate correlated shocks on pension benefits and contributions.

We conducted this study on the Israeli pension system, a representative platform for small open-funded pension systems. Israel has undergone a radical transition from a dominant PAYG-defined benefit (DB) scheme to an almost purely capital-funded scheme with little government intervention. Most of the countries that had undertaken pension reforms wave over the 1990s scaled them back over the last decade (Ortiz et $a l ., 2018)$. However, Israel's pension system is stable with the same consistent 
capitalization trend (Giorno and Adda, 2016). We examine in both conceptual and quantitative terms the development of the two pillars of Israel's pension system and project the future character of the pension system (Cristea and Thalassinos, 2016).

To this day, the Israeli pension system is considered a "black box." As opposed to Germany and Ireland and similar to other countries, the first significant wave of participants affected by the radical pension transition has not yet retired and will do so in the coming years. Only a few studies have been conducted on the Israeli pension system. Most of them, such as Benish et al. (2016), Kimhi and Carmi (2018), and Spivak and Trotsky (2013), have dealt with the influence of management fees on savings and accumulations. Now that these fee rates are very close to the Organization for Economic Co-operation and Development (OECD) average value, it is surprising to see that there is no sufficient debate on pension system design. We hope to reveal in this work some of the future consequences of the radical funded pension fund and contribute to the debate on the proper balance of government intervention in the pension market.

In the first part, we have described the Israeli pension system's unique evolution toward capitalization and minimum government intervention. This policy appears to be consistent with a broader global trend supporting privatization and reducing government involvement. We discuss the socioeconomic challenges that have developed over the years due to this policy. These current challenges are an integral part of any pension targets.

The second part of this paper simulates the expected pension benefits of the first and second pension pillars according to accurate sample data, based on the by-laws of pension funds and the insurance companies in Israel. In fact, to the best of our knowledge, for the first time in pension research in Israel, a study introduces a unique database from the largest pension fund in Israel with more than 15,000 records of wages and savings accumulations. Simulating future benefits, we consider the effect of financial crises on pension benefits from time to time and the realization of financial shocks.

Based on the sample and the simulation results, we determined that adequate pension benefits are applicable only when actuarial assumptions are realized with no fluctuations along the individual's career. We pointed out the system's vulnerability to financial and systemic shocks. These may include unemployment periods, low market returns, wage cuts, and early withdrawal from pension accumulation. Moreover, we show that Israel's pension system provides less room for redistribution and leaves individuals exposed to substantial income inequality and market fluctuations.

Based on the results, we suggest implementing a standard instrument of minimum pension guarantee for two motives: economically, to strengthen the individual's ability to absorb financial risks and socially, to alleviate poverty and inequality. We also claim that based on Central East Europe (CEE) experiences and Latin American 
countries, this tool can increase the system's sustainability (Grech, 2018; Mesa Lago, 2018). To avoid tax raises or an increase in contribution rates, we recommend using internal finance sources and intra-generational risk sharing.

After discussing the Israeli pension system and its characteristics in the first two sections, in Section 3, we describe the sample and the simulation for both the first and second pillars. Section 4 explains the calibration and sets the proper assumptions to run the simulation model for future benefits. Section 5 reports the main results of the simulations. In Section 6, we discuss the results and suggest specific ways to improve the pension scheme's sustainability. Section 7 concludes the paper.

\section{The Evolution of Israel's Pension System}

\subsection{Macro-Economic Processes}

Until 1985, the Israeli economy was centralized and controlled by the government and by an umbrella organization of all labor unions in Israel, "Histadrut," both ruled by the Labor Party (Spivak, 2013). The Histadrut represented $80 \%$ of the workforce and owned 25\% of the economy's capital in all fields, including pension funds (BenPorat, 2008, p. 94). In 1973, when the war and the oil crisis broke out, the government gradually lost control over the economy: The budget deficit in 1980-1984 was 13.2\% of the GDP, and annual inflation stood around 400\% (Ben-Basat, 2002). In 1985, a national unity government in cooperation with employers, Histadrut, and the Bank of Israel (BOI), introduced an economic stabilization program. The program included a price freeze and a sharp reduction in the government deficit.

Alongside governmental efforts to stabilize the economy, the government-initiated pension reforms, designed according to the American agenda, to reduce government involvement (Manor, 2015). The reform's bottom line was to transform the pension scheme from a PAYG DB scheme with low coverage to a defined contribution (DC) scheme with automatic actuarial balance, thus avoiding governmental intervention and fiscal burden. The reforms were not strictly economic but based on neoliberal economic beliefs, political motives, and international relations. The major powerful forces that drove the reforms were the Ministry of Finance (MOF) seniors, the BOI, and the academic community, primarily educated at American universities.

The continuation of pension reforms in the 1990s was led by the 'Likud' party, from the right-wing of the parliament, which has been in power since 1977. It was an opportunity to weaken the organizations affiliated with the Labor Party, mainly the Histadrut (Paz-Fuchs et al., 2018). Alongside impressive macroeconomic results in the Israeli market in the past 30 years, the pension market has completely changed from 'social' to 'liberal' (Ayal, 2011). The pension reforms were intended to stabilize the system and prepare it for future difficulties, such as aging and poverty relief, and eliminate the risk of fiscal challenges in the future. Israel has made significant steps toward minimizing government intervention in the pension market and basing pension benefits on individual contributions and accumulations. 
Israel's pension reform can be compared to those introduced in several Latin American countries, starting with Chile (in the early 1980s), Mexico, and several CEE countries, such as Hungary and Slovakia-which had the extreme view of privatizing national pensions according to a pure DC model (Manor and Ratajczak, 2020). The difference is that Israel continues with the line of capitalization, while most of these countries have rolled back their pension system toward more to favor more significant government intervention and institute a minimum pension guarantee. Indeed, Israel's public expenditure on a pension has decreased constantly and is now one of the lowest among the OECD members, with $4.8 \%$ compared to the average OECD of $10 \%$ (see Figure 1/Panel B).

\subsection{The First Pillar}

The first pillar aims to provide every elderly citizen with a uniform and basic income to reduce elderly poverty. To this end, the National Insurance Institute (NII) provides them old-age allowances and income support. Israel has no target pension, and its basic pension (first pillar) is low, only $14 \%$, on average from the average monthly wage ("NII Report" 2020), compared to $28 \%$ in other OECD members (OECD, 2019).

Israel's basic pension combines the criteria of residency and years of insurance. The residency component is applied when individuals reach retirement age and are contingent on the condition that the retirees have no additional income (aside from pension income) over a pre-determined amount. After the age of 70 (for men) or 6570 (for women, depending on their year of birth), the additional income stipulation is dropped, and all retirees receive an old-age allowance regardless of additional revenues. The basic allowance in 2018 was NIS 1,535 per month. Those who do not receive an allowance from retirement age until age 70 due to income from work or other sources receive an increase of $5 \%$ for every deferred year.

In addition to the residency-based old age allowance, there is a "seniority supplement" based on the number of insurance years (i.e., years in which the individual worked and paid National Insurance taxes) accrued before retirement. This supplement's size is calculated based on $2 \%$ of the old age allowance per full insurance year after the first ten insurance years and can reach a cap of $50 \%$ for individuals who have paid to National Insurance for at least 35 years.

The total seniority supplement awards recipients with an additional $7 \%$ of their average salary. The total average contribution rate stands at $5.3 \%$ from GDP, while the average OECD rate stands at 9.1\% (NII Report, 2020).

\subsection{The Second Pillar}

The second pillar is an occupational pension, in which contributions and the overall savings are derived from past income. In some OECD countries, this pillar is managed by the public system, while in other countries, such as Israel, it has been privatized 
and is managed by for-profit financial bodies. The primary purpose of the occupational pension pillar is ensuring savings at a level that provides pensioners with a reasonable standard of living comparable to the one they had during their working years.

Before the reforms, the occupational pension pillar included the PAYG DB scheme, a tax-financed lifetime annuity plan for soldiers and public servants. Pension savings were not obligatory, as only public sector workers and employees under sectorial agreements were enrolled automatically. Upon retirement, the individual received a guaranteed monthly pension equal to a predetermined percentage of his salary in these schemes. All funded instruments were invested solely in designated governmental bonds. Consequently, around $43 \%$ of the Israeli population did not have any pension arrangement until 2008 , when a mandatory private pension scheme was introduced (Manor, 2015). Besides the low coverage, another problem in the old scheme was profound actuarial benefits. The pension scheme gave generous benefits and lacked a mechanism for adjusting to demographic changes. This system has a history of suffering from large actuarial deficits during the 1980s and 1990s, and in the mid1990s, Israel introduced a significant reform to stabilize its pension system.

In 1995, as part of the pension reform, the 'old' pension funds were closed to new participants ${ }^{3}$. Instead, new members were offered new public DC funds and, later on, only private pension funds. The new pension funds are private DC funds, in which, upon retirement, the individual's benefit is determined by the amount of money accumulated in his fund. Recently it was reported that more than $90 \%$ of the Israeli workforce contribute to the capitalized funded pension funds (Bowers and Fuchs, 2016). The residual is still insured in the old DB public-sector funds. Since the 1970s, the government has been issuing designated bonds with an insured annual real return of $4.86 \%$. In the past, this instrument was efficient for issuing debt from the public in hyperinflation days. Most of the pension portfolio was mandatorily invested in those bonds.

In 2003, the old age allowance linkage to the average wage was abandoned; it was linked instead to the Consumer Price Index, thus halting the gradual increase in the actual value of this allowance. This is not simply a technical issue when real wages are rising, as it means that retired persons' incomes decline about the rest of the population. In the same year, as another step toward pension market capitalization, the coverage rate of designated bonds was reduced to $30 \%$ of pension-accrued portfolios. This reform led pension funds to direct a large portion of savings into the capital market. Since 2017, the allocation of these bonds ("Arad") has been raised to $60 \%$ for savers above the age of $60,30 \%$ for savers in the range of 50-60 years, while the allocation to savers under 50 years of age is being gradually reduced to zero (Sheshinsky and Kalir, 2020).

\footnotetext{
${ }^{3}$ Some other countries have also closed access to DB plans to new members, such as Italy, since 1993. New members have the possibility (in Italy) or the obligation (in Israel) to join DC plans instead.
} 
The subsidy of designated bonds' economic cost has been estimated to be nine billion NIS in 2020 ("General Accountant Report" 2020). In the last three years, the issuing cost has been risen by one billion NIS per year. Consequently, there is a growing debate over reducing the issuance of designated bonds to benefit from the high performance of the capital markets and provide fiscal relief (Achdut, 2015; Sheshinsky, 2017). Some have suggested issuing designated bonds according to people's ages to ensure the stability of return close to retirement, and others have suggested that they be issued as per the participant's wage level. In the following section, we suggest altering the use of designated bonds as the primary financial source to expand public expense on the pension system.

The Israeli government instituted a mandatory pension law to increase the rate of pension savers in the population, effective since January 1, 2008. The mandatory pension implemented in Israel is related to one's income-related (this is also the case in Austria, Belgium, France, Germany, Italy, Norway, Sweden, and the United Kingdom). The mandatory Israeli pension is not expected to bring about a significant improvement in all retired citizens' state. Instead, it is expected to merely reduce government expenditure on retirees' support payments (Gavious et al., 2009). Nevertheless, as of 2015, approximately $40 \%$ of individuals have no pension savings at all, primarily due to poor enforcement of the law (Rubinstein and Levy, 2019). This step made lump-sum withdrawal possible only for mid-high and high-income earners and only at retirement (Ahdut and Spivak, 2010). In addition to the mandatory contribution requirements, the Israeli tax policy also incentivizes private pension savings through generous tax credits for the second and the third pillars.

This year (2015), Israel significantly decreased its public expenditures on public pension (see Figure 1 / Panel B and D). Israel resembles Ireland in this aspect: Its social securities are not the main component of the pension system, and it guarantees only a fundamental pillar. In 2017, pension contributions also became compulsory for the self-employed. The mandatory pension law application attests to the government assumptions that individuals do not plan sufficiently for their future.

The mandatory pension law increased coverage from 35\% in 2009 (OECD, 2011, p. 9) to $78.2 \%$ in 2018 (OECD, 2019), allowing almost $43 \%$ of the population to have a future annuity, thus, reducing future poverty. Major institutions in the capital markets became pension providers, with total assets of 1.2 trillion NIS (which almost equals the annual GDP of Israel), and the growth of accumulation continues with annual contributions of 90 billion NIS and high returns (Bank of Israel, 2019b). Most of the pension accumulation has been placed on the local capital market, while the government's pension finance involvement has dropped from 100\% to around $45 \%$.

The pension field in Israel after the reform does not expose the government to longevity risk. This absolute risk is levied on participants. The system is not supposed to face actuarial challenges or unfunded liabilities that many other OECD countries face. Private pensions in Israel offer insurance on life expectancy, as monthly payments continue until death. An individual's longevity risk is shared among all 
recipients. Those who live longer than expected receive more than they contributed. The opposite is true for those who pass away early. These schemes, thus, include built-in automatic mechanisms that adjust pension levels to life expectancy (Brown, 2014).

In addition to systemic reform, Israel has also conducted parametric reforms in line with other Western countries, addressing the increase in life expectancy. In 2003, the retirement age for men was raised from 65 to 67 and from 60 to 62 for women, and the latter is supposed to be raised further to 64 in the coming months.

\subsection{Social Considerations}

A highly capitalized pension system intensifies economic gaps among earning cohorts. The twofold reasons are the heavy accumulation-accrued effects and, from the other side, differences in the ability to hedge risks among earning cohorts. Hence, the market's socioeconomic starting point is essential to ensure benefits adequacy (Barr and Diamond, 2009).

Nowadays, on the eve of the retirement wave in the new pension scheme, one should ask if the current scheme serves social targets and, if not, how it can serve them. Consequently, it was realized that there existed social gaps in several dimensions:

- Current Poverty and Income Inequality: Nowadays, Israel is considered one of the Western world's unequal economies with a high poverty rate (see Figure 1 / Panel A and C). Israel's tax system intensifies income inequality gaps (Kimhi, 2013). This is illustrated by the spectacular reversal of Israel's international ranking in senior poverty, rated after taking account of taxes and benefits (see Figure 1). Internal Labor Issues: The pension system also suffers from internal labor issues among the Haredim and Arabs communities, who have relatively lower incomes. Positive changes have been observed in these groups lately. Other challenges for the pension system are the current, relatively high poverty rate among pensioners and the absence of good working years for accumulation for Jewish immigrants from Europe, especially from former Soviet Union countries.

- Government Subsidy Anomaly: The issuing of the designated bonds according to the pension portfolio gives subsidies to the higher-earning cohorts, as they are issued in correlation with the portfolio size.

- Gender's Wage Gap: Given the lower average earnings of women and their greater reliance on NII allowances, the growing importance of the second pillar over time relative to the first pillar may cause pension gender gaps in Israel to widen, in a way similar to the high inequality between subcohorts (Bowers and Fuchs, 2018). 
Figure 1. Income Inequality, Old Age Poverty Rate, Pension Public Spending, Social Benefits to Households
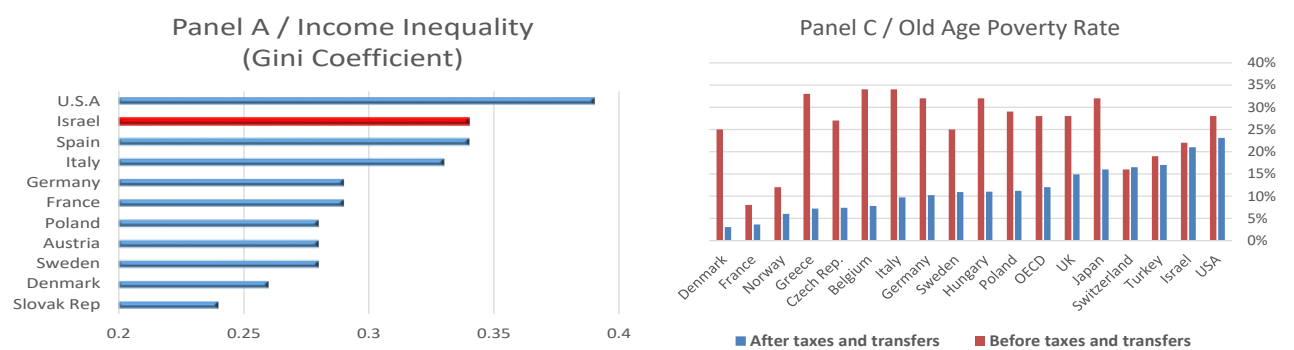

Social Benefits to Housholds (\% of GDP)

Panel B / Pension Public Spending ( $\%$ of GDP)

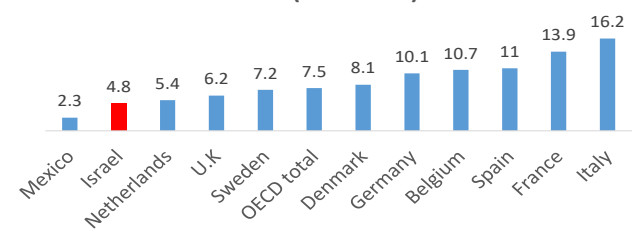

Source: OECD Data, 2020

Source: OECD data, 2020.

\section{Model}

\subsection{Data and Methodology}

This section describes the process to calculate expected pension benefits from both pension systems' pillars. We based this research on a unique database obtained from the most significant private pension fund in Israel ("Menora Insurance and Pension Company").

We obtained 15,000 accurate random records of wage and informative data, such as participants' ages, genders, and family statuses. Furthermore, each record includes their financial information: current insured wage, contribution rates, current accumulation, and private pension coefficient. All the financial data are in the 2019 currency level. From a single point in time in 2019, we managed to draw a future wage path for each participant until retirement, based on predetermined wage development assumptions. From that, we derived the future contributions, pension accumulations, and future benefits for each sample participant. Accordingly, we analyzed these future benefits according to age cohorts and earning deciles.

We considered two correlated risk variables affecting wage path and pension benefits: GDP per capita and annual private pension return. We linked the participants' wages and social security allowances to GDP per capita and their capitalized pension returns to a stochastic pension rate of return. 


\subsection{Wage Path}

In order to calculate pension accumulation at retirement, wage development through the individual career was required. Some scholars have conducted wage simulations based on statistical regression for different Israeli society cohorts (Carmi and Kimhi, 2018; Manor, 2020; Spivak et al., 2017). Here, on the other hand, the model is based on accurate wage records from a private pension fund. We obtained 15,000 participants' sample wages and pension accumulations in terms of the 2019 currency level. To draw their future wage paths until retirement, we indexed each wage to record the annual change of GDP per capita as a function of their earning decile. A participant's wage in the year $\mathrm{t}+1$ can be described as follows:

$$
W_{i, t+1}=W_{i, t} *\left(E_{t} a_{i}\right) g_{t}
$$

Where $\mathrm{W}(\mathrm{i}, \mathrm{t}+1)$ represents the $\mathrm{i}$ participant's wage in the year $\mathrm{t}+1$. $\mathrm{E}_{\mathrm{i}}$ stands for the earning decile indexing from the GDP per capita annual rate of change, $g_{t} . a_{i}$ represents the age indexing factor. We expressed differentiation in earning cohorts by recognizing GDP growth distribution according to earning cohorts $\left(\mathrm{E}_{\mathrm{i}}\right)$. We assumed there is no shift in earning decile along with a participant's career; thus, the decile-indexing coefficient for each participant is constant. For this assumption, we relied on Spivak (2015) and Carmi and Kimhi (2018), who investigated Israel's labor market.

\subsection{The First Pillar}

Each period, the working population's contributions are equal to total benefit payments to retirees. Consequently, the public unfunded pension benefit is determined by the balance budget condition, which is as follows:

$$
\tau^{U} \bar{W}_{t+1} N_{t+1}=p_{t, T_{R}}^{U} N_{t}
$$

Here, $\tau^{U}$ is the contribution rate to unfunded social security, $N_{t}$ represents the size of the generation born in the period, and $p_{t, T_{R}}^{U}$ is the unfunded pension benefits paid to generation $t$ in the period of $T_{R}$. Due to the assumption of a constant debt ratio, the PAYG pillar has a balanced budget mechanism in every period.

Under the assumption of constant population growth, the contribution $\tau^{U} w_{t, s}$ is paid by the generation $t$ in time $s$. We indexed the real PAYG annual rate of return to the annual growth of the GDP per capita with a specified lag (Chen et al., 2014).

\subsection{The Second Pillar}

The funded fund's expected pension benefit depends on a participant's accrued balance throughout their active phase. The employee and the employer contribute the fraction $\gamma \tau \mathrm{w}_{\mathrm{t}}$ from the insured salary. Pension accumulations are invested in securities 
in the free market and designated bonds (30\% of the portfolio). The fund deducts insurance premiums $\varnothing$ from contributions for spousal benefits and disability risk. Likewise, the fund charges a management fee of $M$ from the contributions. The accumulations earn, on average, the annual rate of return $r_{t}$. This rate of return also follows "Brownian motion" in the following way:

$$
d r_{t}=\mu_{r} d t+\sigma_{r} B^{A} d t
$$

Here, $\sigma_{r}$ is a constant standard deviation and $B^{A}$ the standard Brownian motion. The first phrase from the left is a constant drift, and the second phrase is the volatility drift, respectively. The funded pillar is equal to the accumulated capital from the contributions to the private collective DC fund in every working period until retirement $\left(T_{R}\right)$ :

$$
p_{t+1}^{F}=\tau^{f}\left[A_{t}^{F}+(1-\emptyset) \gamma \tau \sum_{s=t}^{T_{R}} W_{t, s}\left(1+r_{t}-M\right)^{T_{R}-t}-\varepsilon_{t}\right] / \theta
$$

Where, $A_{t}^{F}$ is an individual's pension accumulation at time $\mathrm{t}$ and $\tau^{\mathrm{f}}$ is the effective tax rate on old age funded fund's benefits. $\varepsilon^{t}$ is the personal withdrawal amount from the severance pay component in year $t$. Based on trend reports from the pension fund, we assumed that some of this compensation payment is withdrawn for private consumption until the early 40 s.

Upon retirement, the funded pension allowance is determined by dividing the accrued balance on retirement day by a coefficient $\theta$, which the pension fund determines. This coefficient generally represents the average number of months left from retirement until death and is a function of a participant's gender and retirement age. The pension funds occasionally update these coefficients to maintain actuarial balance.

Here, it should be mentioned that private pensions in Israel offer insurance on life expectancy as monthly payments continue until death. Those who live longer than the average life expectancy receives more than they contribute and the opposite is applicable for those who pass away early.

Private pension allowances are taxed as regular income at the time of collection with an exemption up to NIS 800,000 on discounted accumulations at retirement age. This exemption is reduced for every withdrawal, for compensation accrues in the fund during the operational phase. Due to the high diversity in these withdrawals, we found it impossible to consider the net benefits through this model, and hence, we provided the benefits in gross terms.

Due to the 2020 pandemic, the economic crisis provided us with an opportunity to examine the influence of correlated risks on old-age benefits in the labor market and capital markets. We implement a unique stress scenario as per 2020 data based on the Ministry of Finance's (MOF) economic forecast: 
- Reduction in pension returns to (-4\%) in the year 2020;

- Wage reduction by $30 \%$ in $2020,20 \%$ in 2021 , and $10 \%$ in 2022 with respect to the 2019 wage level with a floor of the minimum wage level;

- Period of unemployment for 6 months in 2020.

\subsection{Minimum Pension Guarantee}

Due to the prevalence of the socio-economic challenges of high poverty and income inequality in the Israeli market, we considered the potential effect of incorporating a universal minimum benefit guarantee. The guarantee increases governmental intervention level in the market as a redistributive top-up to the public pillar (Wolf and Ocerin, 2021). Mixed pension system designs have been implemented in many Western countries, such as Sweden, Switzerland, France, Germany, Italy, Spain, and Portugal (Fajnzylber, 2019), to meet the European Commission's 2020 target (Cantillon et al., 2017).

Alongside simulating the effect of the minimum pension guarantee on expected benefits, we mapped the burden of the guarantee on the market and its economic cost. Considering the financial sources for the guarantee, we referred to some public social programs. The significant financial burden that may be considered a substitute to the guarantee is the issuance of designated bonds. The government is capable of raising a fortune at lower prices in the open market. From an individual angle, these bonds would no longer be relevant if the government ensured benefits adequacy through the minimum pension guarantee. Moreover, the return guarantee rate, provided by the designated bonds, is ineffective when there are insufficient contributions due to labor market fluctuations and systemic risks due to correlations between returns and the labor market (De Menil et al., 2016). From a social perspective, similar to tax incentives, the benefit is mainly embodied in earmarked bonds and reduced risks, and smoother returns over time are regressive up to relatively higher income levels. The reason is that the benefit is extended proportionally; thus, high-wage earners benefit more (Spivak, 2015).

The second source for financing the guarantee is the expected available budget from reducing budgetary pensions spending for public servants and soldiers in the coming years (see Fig. 2). These population cohorts were the last to shift to the new pension model. Nominally, the budgetary cost peak is expected in the year 2039, with a 38.21 billion NIS budgetary expense and fiscal relief after that (Geva, 2013; MOF, 2020). The third source is unique social security benefits for low-income families with an elderly population in addition to the flat universal benefit. According to the NII report, this amount came to almost 1.9 billion NIS in 2020. To keep our number conservative, we indexed this amount to the GDP per capita with a lag. 


\section{Calibration}

The simulation is calibrated based on the Israeli market and consistently with Wolf and Lopez del Rio (2021b). Informative data is drawn from the public statistical agency (CBS), the regulator (Ministry of Finance), or the OECD data bank.

Figure 2. Public Servants - Residual of Budgetary Pensions, \%GDP

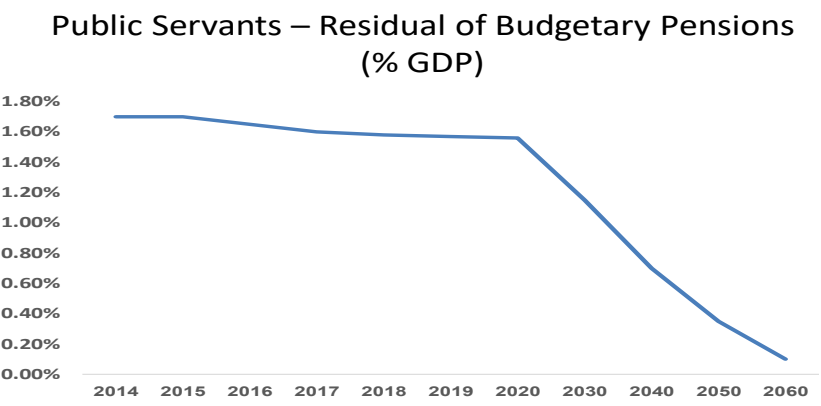

Source: MOF estimates, financial statement, 2018.

\subsection{First Pillar}

Based on the NII rules described above, the maximum amount for an individual in 2020 stood at NIS 2,300 a month. For comparison's sake, the poverty line is about NIS 3,800 per month. Due to the low variety of different benefits and simplicity, we assumed an average essential benefit of NIS 1,800 (in 2020 prices) indexed to the stochastic annual GDP per capita with a lag of 0.5\% (Manor and Rajaczak, 2020).

\subsection{Second Pillar}

The average real return on private funds between 2005 and 2014 amounted to $4.5 \%$. According to research performed for this paper based on MOF data, the annual real average return in 2001-2019 was 6.04\%. For the sake of comparison, the average OECD return in those years stands at $2.5 \%$ (Giorno and Adda, 2016). The standard deviation of returns has risen, from $10.26 \%$ in 2010 to $14 \%$ in 2020 . Some of this has been because of the reduction in designated bonds' issuance to no more than $30 \%$.

We calibrated the gross return as per the actuarial regulator instructions (to private funds). Accordingly, we set an average annual gross private pension fund return of $4.25 \%$. As we did not obtain data on administration fees, we assumed an average fee of $0.5 \%$ from total accumulation for all records. We felt comfortable with this assumption, as administrative fees have been reduced significantly over the last decade to the average levels of OECD countries.

Pension contribution rates to the second pillar vary between $20.83 \%$ and $22.83 \%$ of salary, depending on the workplace, including an employer contribution rate of 6 $8.33 \%$ for severance pay (Ministry of Economy, 2019). Israel's total contribution 
level is located in the middle, relative to other OECD countries, with about $2 \%$ of GDP (OECD, 2019). Severance pays constituted $40 \%$ of the accumulation but can be withdrawn free of tax if one is laid off.

While making the simulation for an individual's entire career, we considered cyclical difficulties in the labor market from time to time. For example, around $40 \%$ of the severance pay is withdrawn for different reasons such as housing, marriage, and consumption between jobs (Spivak, 2013). Those who are young or have a low salary tend to withdraw their severance pay entirely. Accordingly, we assumed two liquidation times for severance pay along with the participants' career as follows:

a. Liquidation rate of $20 \%$ from accumulation at the age of 35 ;

b. Liquidation rate of $20 \%$ from accumulation at the age of 42 .

Additionally, based on CBS and the NII, we assumed two unemployment periods of three months each at the ages of 35 and 45 and another six-month unemployment period at the age of 55. The numeric assumptions for the calibrations have been summed in Table 1.

Table 1. Model Calibration

Model Calibration

\begin{tabular}{|l|c|l|c|}
\hline \multicolumn{2}{|c|}{ Wage indexing to GDP per Capita } & \multicolumn{2}{c|}{ Social levels } \\
\hline Decile 1 & $0.75 \mathrm{GDP}$ per capita & Average wage (2020 prices) & 10,948 NIS \\
\hline Decile 2 & $0.85 \mathrm{GDP}$ per capita & Minimum wage (2020 prices) & 5,300 NIS \\
\hline Decile 3 & $0.95 \mathrm{GDP}$ per capita & Minimum wage indexing & $(1-0.5 \%)$ GDP per capita \\
\hline Decile 4-7 & $1 \mathrm{GDP}$ per capita & Poverty line (2020 prices) & 3,800 NIS \\
\hline Decile 8 & $1.05 \mathrm{GDP}$ per capita & Poverty line indexing & $(1-0.5 \%)$ GDP per capita \\
\hline Decile9 & $1.15 \mathrm{GDP}$ per capita & Social swcurity benefit & $(1-0.5 \%)$ GDP per capita \\
\hline Decile 10 & $1.25 \mathrm{GDP}$ per capita & \multicolumn{1}{c|}{ Sytemic Shock - 2020 } \\
\hline \multicolumn{2}{|c|}{ Funded capitalized fund } & Private pension return & $-4 \%$ \\
\hline Average gross rate of return & $4.24 \%$ & Wage cut 2020 & $-30 \%$ \\
\hline Average net rate of return & $3.74 \%$ & Wage cut 2021 & $-20 \%$ \\
\hline Average insurance premiums fro & $15 \%$ & Accumulation withdraw 2020 & $-20 \%$ \\
\hline Average Contribution rate & $21.83 \%$ & Unemplyment period 2020 & 6 month \\
\hline
\end{tabular}

Source: Calibration based on the Israeli pension market, CBS 2020.

\section{Main Insights}

\subsection{Coverage Rate and Late Enrollment}

The sample data points to a higher coverage rate for the second pillar among highearning cohorts than low-earning cohorts. Due to the 2008 expansion order, we believe that the coverage rate will improve gradually shortly. According to Giorno and Adda (2016), the stubbornly high elderly poverty rate is associated with the low level of first pillar pensions combined with the enrollment to the second pillar. Around half of the older adults do not receive income from the second pillar pensions and probably receive little or no private pension even though many have housing 
wealth (Behr et al., 2013; Bleikh, 2016). According to the sample, 30\% of the workforce, who belong to low earning cohorts, are not covered by private pension plans (see Figure 3). First, the two pillars' total contribution rates are sub-optimal for low earning cohorts (Wolf, Caridad, and Ocerin, 2021). Hence, a low-income earner might prefer current consumption to future savings. Another explanation might be a "black economy," as in for low-earning cohorts, some incomes are not declared or taxed (Spivak and Tzemach, 2017; Gavious et al., 2009). The third explanation is explicitly linked to the Israeli market. During the 1990s, more than a million Jews immigrated to Israel from Eastern European countries after the USSR collapses with no pension accumulations. Many of them still do not have a pension balance (Spivak, 2013).

Figure 4. Sample Coverage per Earning Decile

Private Capitalized Fund Sample / Income

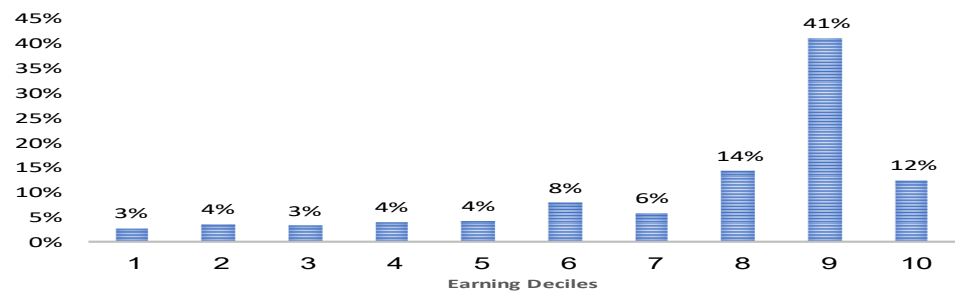

Source: Author's Calculations on 'Menora' DB Sample, August 2019.

\subsection{Benefit Adequacy}

Today's primary beneficiaries from occupational pensions worked in the public sector and are entitled to a budgetary pension or those who had pension arrangements as part of collective agreements in the private sector (Bleikh, 2016; Spivak et al., 2017). Participants above the age of 55 who were not entitled to DB or budgetary pensions (soldiers and former public servants) have enrolled for the funded pension fund late and will mainly benefit from the low social security allowances. This trend was also observed by Spivak and Troisky (2013).

According to Panel A in Figure 5, even in the three higher-earning deciles, workers near retirement will be entitled, on average, to only $71 \%$ of the minimum wage. Due to their late enrolment, we cannot track other savings of the transition generation. Not all of these people are poor, as some of them have accumulated other savings, have housing and are entitled to capital as per the third pillar. However, some of these veterans do not have sufficient old age resources for an adequate standard of living.

Due to the late enrollment of the transition generation, we considered the expected benefits of the current younger workers (under the age of 60) as representative of the pension system. Most of these participants have been contributing to the second pillar from the early stages of their careers. The left bars in Figure 6/Panel B represent the average replacement rates with no minimum guarantee relative to the average wage 
and the career. For low-earning deciles, the replacement level is high because of their extreme poverty during the operational phase and their heavy reliance on the flat universal social security benefits at retirement. For the middle-earning deciles (4-7), we observed that the replacement rates are reasonable and close to the average replacement rates in OECD countries (OECD, 2019). For example, the replacement rate for the middle-earning cohorts with no guarantee $(54 \%)$ is close to the parallel replacement rate in the US (55\%), Switzerland (57\%), Canada (49\%), and the UK $(50 \%)$. The high earning deciles' replacement rates are close to those in Belgium (35\%) and Germany (28\%).

Figure 5. Panel A: Worker's Total Expected Benefits Near Retirement (Age>55)

Panel A: Workers' Total Expected Benefits Near Retirement (Age>55)

Source: Own creation.

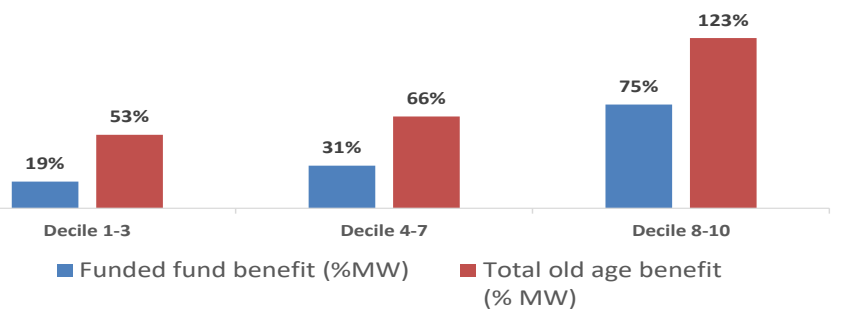

Figure 6. Young Worker's (age<60) Replacement Rated

Young Workers (age <60) Replacement Rated

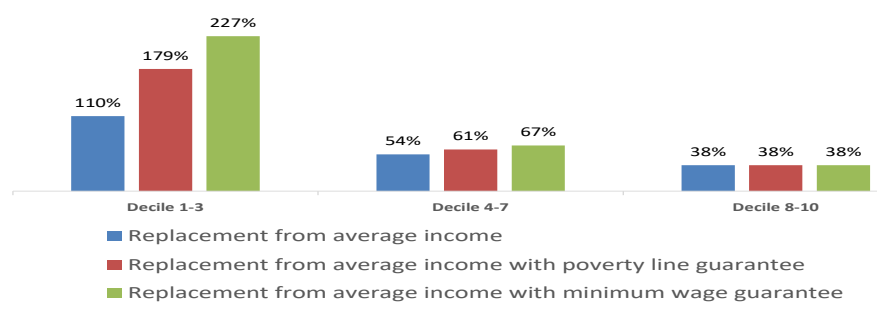

Source: Own creation.

According to Panel B, the results indicate that, on average, the expected benefits of earning deciles 1-7 are beneath the poverty line (where the middle bar is higher than the left bar). The expected benefits at earning deciles 8, 9, 10 will be $100 \%, 150 \%$, and $300 \%$ of the minimum wage level, respectively.

\subsection{Sensitivity Analysis}

The mix between the dominant funded pillar and low social security allowances results in high pension benefits to fluctuations in the market. We observed a $1 \%$ increase in the funded pension pillar's annual return increases accumulation by about 
$20 \%$ and average replacement rates by $5 \%$.

Table 2 summarizes the 2020 systemic shock's influence and its components on expected benefits as a function of the age cohort. For any age cohort, even a substantially low first pillar (less than half from the poverty line) provides diversification effects to some extent. This gets realized in 3-8\% of benefit levels as the difference between the change rates in Table 2/Panels A and $\mathrm{B}$. The reason is the PAYG social security's weak correlation to funded accumulation (Barr and Diamond, 2009; Holzmann and Hinz, 2005). As pointed in Table 2 / Panel A, the hedge in the mixing system is more effective in old age compares to a younger age.

Furthermore, we ascertained that even short systemic shocks leave traces on future expected benefit levels. Although the participant is younger, the shock is less significant than an individual close to retirement, it does not disappear. From Panel A, we study that the systemic shock in 2020 is expected to influence $13 \%$ on average on participants that have more than 25 years until retirement.

Isolating the risk components may contribute to an understanding of long-term influences. By analyzing the different age cohorts, we determined that time differently influences the risks. The market risk's standard deviation smoothens the return over the years; thus, losses at a singular point in time may be compensated in the future (Goecke, 2013). However, the lag in contributions due to wage reductions, unemployment, or capital withdrawal increases over time because of the interestaccrued effect.

Table 2. Expected Benefits by Age

Expected Benefits by Age

\begin{tabular}{|c|c|c|c|}
\hline \multicolumn{4}{|c|}{ Panel A: Funded Pillar Benefits (current prices, NIS) } \\
\hline $\begin{array}{c}\text { Participan's } \\
\text { Age }\end{array}$ & $\begin{array}{c}\text { No Systemic Shock in } \\
2020\end{array}$ & \begin{tabular}{|c|}
$\begin{array}{c}\text { With Systemic shock } \\
\text { in } 2020\end{array}$ \\
\end{tabular} & Change \\
\hline$<40$ & 9,222 & 7,891 & -14 \\
\hline $40-55$ & 4,927 & 4,352 & -12 \\
\hline$>55$ & 1,794 & 1,612 & -10 \\
\hline \multicolumn{4}{|c|}{ Panel B: Total Benefits (current prices, NIS) } \\
\hline $\begin{array}{c}\text { Participan's } \\
\text { Age }\end{array}$ & $\begin{array}{c}\text { No Systemic Shock in } \\
2020\end{array}$ & \begin{tabular}{|c|} 
With Systemic shock \\
in 2020
\end{tabular} & Change \\
\hline$<40$ & 11,771 & 10,583 & -10 \\
\hline $40-55$ & 7,074 & 6,499 & -8 \\
\hline$>55$ & 3,610 & 3,453 & -4 \\
\hline
\end{tabular}

Source: Own creation.

\subsection{Minimum Pension Guarantee}

A minimum pension guarantee has been revealed to be highly effective for benefit redistribution and avoiding poverty in old age. Figure 5 / Panel B reports that a poverty line guarantee is effective for the first seven earning deciles under 60. As seen in Figure 6, we calculated the expected guarantee cost based on the minimum wage levels and the poverty line. The guaranteed cost will be relatively high in the 
next fifteen years due to lack of coverage as per the second pillar described above. In Figure 6, we show that by redirecting the subsidy inherent in the issuance of the designated bonds, the government, from Day 1, can finance the guarantee at the poverty line level ${ }^{4}$. Through this solution, the government can improve pension benefits adequacy at a lower cost than by issuing these bonds. Furthermore, this solution can also provide adequate pension benefits to the transition generation, including new immigrants with low accumulations and participants who enrolled late to the second pillar.

Furthermore, in thirty years, the government could afford to finance a minimum pension guarantee at the minimum wage level. The reason for this is the realization of two trends. The first one is the retirement of the transition generation, whose total benefits are relatively low and will need governmental supplements in the coming years, which will reduce gradually over the years. The second is the expected increase in the alternative cost of the designated bonds. The government can afford to finance the guarantee at the minimum wage level earlier, in 2048, if it utilizes. Also, the available budget reduced budgetary pensions and other means-tested for old age (see Figure 6, Panel B).

Figure 7. Panel A: Minimum Pension Expected Cost (million NIS, current prices)

Panel A: Minimum Pension Expected Cost (million NIS, current prices)

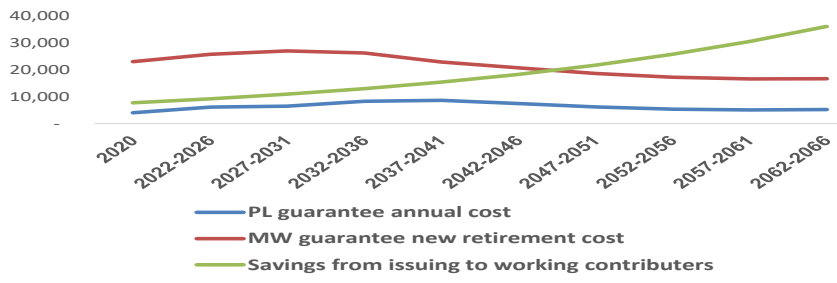

Source: Own creation.

Table 3. Panel B: Minimum Pension Expected Cost (million NIS, current prices)

Panel B: Minimum Pension Expected Cost (million NIS, current prices)

\begin{tabular}{|c|r|r|r|r|r|}
\hline Year & $\begin{array}{c}\text { MW guarantee } \\
\text { new retirement } \\
\text { cost }\end{array}$ & $\begin{array}{c}\text { Savings from } \\
\text { issuing to working } \\
\text { contributers }\end{array}$ & $\begin{array}{c}\text { Saving from } \\
\text { budgetary } \\
\text { pensions* }\end{array}$ & $\begin{array}{c}\text { Saving from } \\
\text { means-teted }\end{array}$ & Total savings \\
\hline 2020 & 23,075 & 7,740 & - & 1,884 & 9,624 \\
\hline $2022-2026$ & 25,834 & 9,210 & - & 1,999 & 11,209 \\
\hline $2027-2031$ & 27,095 & 10,954 & - & 2,122 & 13,076 \\
\hline $2032-2036$ & 26,319 & 13,019 & - & 2,252 & 15,271 \\
\hline $2037-2041$ & 22,967 & 15,464 & - & 2,391 & 17,855 \\
\hline $2042-2046$ & 20,804 & 18,357 & 2,500 & 2,537 & 23,394 \\
\hline $2047-2051$ & 18,671 & 21,776 & 5,000 & 2,693 & 29,469 \\
\hline $2052-2056$ & 17,296 & 25,812 & 7,500 & 2,858 & 36,170 \\
\hline $2057-2061$ & 16,645 & 30,573 & 10,000 & 3,034 & 43,607 \\
\hline $2062-2066$ & 16,715 & 36,182 & 12,500 & 3,220 & 51,902 \\
\hline
\end{tabular}

Source: Own creation.

${ }^{4}$ We assume that certain designated bonds will still be issued to retirees. 


\section{Discussion}

Poverty is expected to increase among those who lack an adequate second pillar pension arrangement, with the limited social security allowance being their sole income. Special attention has to be given by the central planner to the first generation of retirees from the new pension model. Many have enrolled late in the mandatory pension system, and their benefits are relatively low. Some of them are new Jewish immigrants from Europe and Russia from the large immigration wave during the 1990s.

The results confirm Boelaars and Broeders' (2019) argument that market risk depends on the residual time of pension contribution. Individuals near retirement are more exposed to capital market fluctuations. We also determined a high correlation between an individual's career path and pension accumulation. Job tenure risk, other labor risks, and systemic risks leave traces for years until retirement. Furthermore, the results indicate that a systemic shock, even in the preliminary stages of an individual's career, might have consequences in a large share of the old-age population below the poverty line.

The state strategy to avoid its redistributive role is consistent with a particular economic rationale (Wolf and Lopez del Rio, 2021a). However, extending occupational pensions to all workers on elderly people's revenue is also affected by how long people have contributed, and it will, therefore, be many years before the policy takes full effect (Giorno and Adda, 2016).

The results further suggest the high effectiveness of a total minimum pension guarantee. The guarantee significantly improves low-earning replacement rates, increases redistribution, and may avoid poverty in old age. For example, the poverty line guarantee is effective for the first seven deciles. Based on the high portion of oldage poverty and income inequality, we found focusing on total benefit valuable compared to returns on the funded fund.

\section{Conclusion}

This paper's objective was to determine the long-term effect of the Israeli pension system as an almost purely DC-funded scheme and investigate the risk to future pension benefits in a dominant-funded fund. We found Israel as a unique playground for examining the consequences of the global trend of a decrease in government interventions and capitalization in the pension markets. We calculated the expected pension benefits and allowances during old age based on accurate pension records and the pension simulator.

The simulation results indicate that younger workers, even from lower-earning cohorts who consistently keep contributing to pension funds, will most likely move away from the poverty line at retirement. However, even short periods, along the entire career, of reductions in contribution and systemic risks jeopardize the adequacy 
of benefits during retirement. Moreover, we found it challenging to ensure adequate benefits for the transition generation who enrolled in the pension system late. Most likely, the government will have to find a one-time solution for low benefits.

We determined that the pension scheme was significantly vulnerable to systemic risk due to its heavy reliance on accumulations along with the career and the capital markets' performance. An individual might find themselves unemployed with no contributions and reduce their cumulative pension balance due to low market returns. We suggest considering more weight on the public pillar to institute a minimum pension guarantee plan. We discovered that, by implementing a minimum pension guarantee, there could be a significant improvement in replacement rates and total benefits.

We suggest that the guarantee be financed by amortizing designated bonds, abolishing means-tested substitute programs, and redirecting available budget for old budgetary pension expenses. Furthermore, we attributed the underlying asset as total pension benefits.

We demonstrated the irrelevance of the claim that the capital market would balance out over decades of retirement savings. This claim, which was the basis of the World Bank's agenda in 1994 and the Israel Ministry of Finance until the present, ignores the risks and fluctuations in both the financial and the labor markets (Carmi and Kimhi, 2018). The simulation in this study confirmed Barr and Diamond (2009) that relying solely on the funded pillar meant neglecting the possibility of risks, such as volatility of returns, fluctuations in the labor market, and the existence of systemic risks from time to time. Recently, the COVID-19 pandemic has demonstrated individuals' susceptibility to volatile market fluctuations. Pension schemes with high market exposures are expected to suffer the most from these crises.

Further research is needed for the micro-examination of the expected pension benefits, such as gender gaps, sub-cohorts in society, etc. Additionally, one might choose to delve into the consequences of different systematic shocks and realizations on pension benefits in this era of financial crises and labor market challenges further. Such studies will enrich the discussion of the right ways to implement modern funded pension schemes for achieving social targets.

\section{References:}

Ahdut, L., Spivak, A. 2010. The pension system in Israel after 15 years of reforms. Van Leer Institute, Jerusalem.

Benish, A., Haber, H., Eliahou, R. 2016. The regulatory welfare state in pension market: mitigating high charges for low-income savers in the United Kingdom and Israel. Journal of Social Policy, 1-18. ISSN 0047-2794.

Bleikh, H. 2016. Poverty and inequality in Israel: An international perspective. LIS Working Paper Series 661. http://hdl.handle.net/10419/169221. 
Boelaars, I., Broeders, D. 2019. Fair pensions. De Nederlandsche Bank, Working Paper No. 630. Available via SSRN. https://ssrn.com/abstract=3374456. http://dx.doi.org/10.2139/ssrn.3374456

Bowers, L., Fuchs, H. 2016. Women and parents in the labor market-Israel and the OECD. Available via Taub Center. http://taubcenter.org.il/wpcontent/files_mf/womenandparents_eng.pdf.

Carmi, S., Kimhi, A. 2018. A primer on Israel's pension system Where it is Today and Suggestions for the Future. Shoresh Institute for Socio-Economic Research, Jerusalem.

Chen, D., Beetsma, R., Ponds, E., Romp, W. 2014. Intergenerational risk-sharing through funded pensions and public debt. CESifo Working Paper Series No. 4624. Available via SSRN. https://ssrn.com/abstract=2400979.

Cristea, M., Thalassinos, I.E. 2016. Private Pension Plans: An Important Component of the Financial Market. International Journal of Economics and Business Administration 4 (1), 110-115. DOI: 10.35808/ijeba/95.

De Menil, G., Murtin, F., Sheshinsky, E., Yokossi, T. 2016. A rational, economic model of PAYG tax rates. European Economic Review, 89, 55-72.

Gavious, I., Spivak, A., Yosef, R. 2009. Pension reform in Israel under mandatory pension law. Pensions: An International Journal, 14(1), 4-13.

Giorno, C., Jacques, A. 2016. Improving the pension system and the welfare of retirees in Israel. OECD, Working Paper, No.1288. OECD Publishing, Paris.

Goescke, O. 2013. Pension saving schemes with return smoothing mechanism. Insurance: Mathematics and Economies, 53(3), 678-689. https://doi.org/10.1016/j.insmatheco.2013.09.010

Hakohan, R. 2014. Employment among elders in Israel. Policy Paper. Israeli employment service, Jerusalem. Retrieved from: https://www.taasuka.gov.il/he/InfoAndPublications/Documents/ adultsemployment0214.pdf.

Kimhi, A., Kyrill, S. 2013. Employment and income trends among older Israelis. In: Dan Ben-David (ed) State of the nation report: Society, economy, and policy in Israel. Taub Center for Social Policy Studies in Israel, 119-162, Jerusalem.

Manor, M., Ratajczak, J. 2020. Shift to private pension system: The case of Poland and Israel. Economics and Business Review 6(1). https://doi.org/10.18559/ebr.2020.1.4

NII Financial Report to 2019. Retrieved from: https://www.btl.gov.il/Publications/Financial\%20reports/Documents/mazan2018. pdf

Paz-Fuchs, A., Mandelkern, R., Galnoor, I. 2018. The privatization of Israel: The withdrawal of state responsibility. Springer Books, Palgrave Macmillan, New York. https://doi.org/10.1057/978-1-137-58261-4.

Spivak, A., Tzemah, S., Carmel, E. 2017. Israel pension reform. Van Leer Institute, Jerusalem.

Stier, H., Bleikh, H. 2014. Poverty within the elderly population in Israel. In: Dan BenDavid (ed) State of the nation: Society, economy, and policy. Taub Center for Social Policy Studies in Israel, Jerusalem, 393-434.

Thalassinos, E., Cristea, M., Noja, G.G. 2019. Measuring active ageing within the European Union: implications on economic development. Equilibrium. Quarterly Journal of Economics and Economic Policy, 14(4), 591-609. https://doi.org/10.24136/eq.2019.028. 
Wolf, I., Lopez del Rio, L. 2021a. Pension e-forms and Risk Sharing Cycle: A Theory and Global Experience. International Journal of Economics \& Business Administration (IJEBA), 9(1), 225-242.

Wolf, I., Lopez del Rio, L. 2021b. Funded-capitalized pension designs and the demand for minimum pension guarantee. Public and Municipal Finance, 10(1), 12-24. doi:10.21511/pmf.10(1).2021.02.

Wolf, I., Ocerin, J.M.C. 2021. The transition to a multi-pillar pension system: the inherent socio-economic anomaly, Journal of Financial Economic Policy. https://doi.org/10.1108/JFEP-07-2020-0162. 